ISSN 0258-7122 (Print), 2408-8293 (Online)

Bangladesh J. Agril. Res. 43(4): 557-574, December 2018

\title{
RESPONSE OF BROCCOLI TO USG AND PRILLED UREA IN SHALLOW RED-BROWN TERRACE SOIL UNDER MADHUPUR TRACT
}

\author{
M. J. HUSSAIN ${ }^{1}$, A. J. M. S. KARIM ${ }^{2}$, A. R. M. SOLAIMAN ${ }^{2}$ \\ M. S. ISLAM ${ }^{2}$ AND M. RAHMAN ${ }^{3}$
}

\begin{abstract}
A field experiment was conducted at Bangabandhu Sheikh Mujibur Rahman Agricultural University, Gazipur during the period from 2012-13 to verify the effectiveness of urea super granule (USG) and prilled urea (PU) on the yield and quality of broccoli, to assess the comparative performance of USG and PU on nutrient uptake and nitrogen use efficiency and to evaluate the effect of USG and PU on post-harvest nutrient status in Shallow Red-Brown Terrace Soil of Madhupur Tract (AEZ-28). The experiment was designed in a randomized complete block with three replications having 5 treatments as $\mathrm{T}_{1}$ : Control, $\mathrm{T}_{2}$ : USG-N $\mathrm{N}_{140}, \mathrm{~T}_{3}$ : USG-N $\mathrm{N}_{160}, \mathrm{~T}_{4}$ : USG-N $\mathrm{N}_{180}$ and $\mathrm{T}_{5}$ : PU-N $\mathrm{N}_{180}$. Result showed that USG performed better than PU. The comparative performance of USG in relation to yield, head quality (ascorbic acid, $\beta$-carotene and chlorophyll content), SPAD value, nutrient (NPKS) uptake and N use efficiency was found higher as compared to PU. USG treated broccoli plants gave significantly higher yield where the highest yield (13.49 ton ha ${ }^{-1}$ ) was recorded with USG- $\mathrm{N}_{160} \mathrm{~kg}$ $\mathrm{ha}^{-1}$. Moreover, USG showed higher $\beta$-carotene and chlorophyll content over PU and those were increased with increasing levels of N. However, ascorbic acid content was slightly decreased with increasing rate of $\mathrm{N}$ fertilizer. Nitrogen, phosphorus and potassium uptake increased with increasing $\mathrm{N}$ rate upto USG$\mathrm{N}_{180}$ but sulphur uptake was increased upto USG- $\mathrm{N}_{160}$. Nitrogen use efficiency was higher in USG treated plots than that of PU having the highest value of $111.71 \%$ with USG-N $\mathrm{N}_{160} \mathrm{~kg} \mathrm{ha}^{-1}$. Post-harvest soil nutrient status was not significantly influenced by the treatments although it was slightly higher in USG as compared to PU. Considering all, USG @ $160 \mathrm{~kg} \mathrm{~N} \mathrm{ha}^{-1}$ (USG-N ${ }_{160}$ ) with other recommended fertilizers (@ $53 \mathrm{~kg}$ P, $83 \mathrm{~kg} \mathrm{~K}, 20 \mathrm{~kg} \mathrm{~S}, 2.0 \mathrm{~kg} \mathrm{Zn}, 1 \mathrm{~kg} \mathrm{~B}$ and $0.8 \mathrm{~kg} \mathrm{Mo} \mathrm{ha}^{-1}$ ) could be the best USG based fertilizer dose for quality broccoli production in Shallow Red-Brown Terrace Soil of Madhupur Tract.
\end{abstract}

Keywords: Broccoli, USG, head quality, chlorophyll content, nitrogen use efficiency, soil nutrient status.

${ }^{1}$ Senior Scientific Officer, Soil \& Water Management Section, Horticulture Research Centre, Bangladesh Agricultural Research Institute (BARI), Gazipur, ${ }^{2}$ Professor, Department of Soil Science, Bangabandhu Sheikh Mujibur Rahman Agricultural University (BSMRAU), Gazipur, ${ }^{3}$ Professor, Department of Hoticulture, BSMRAU, Gazipur, Bangladesh. 


\section{Introduction}

Broccoli (Brassica oleracia var. italica L.) is one of the winter vegetables belonging to the family Cruciferae. It is a beneficial and more nutritious vegetable than any other of the same genus (Yoldas et al., 2008). It is well known that, broccoli has enormous nutritional and medicinal values due to its high contents of vitamins (A, $\mathrm{B}_{1}, \mathrm{~B}_{2}, \mathrm{~B}_{5}, \mathrm{~B}_{6}$ and $\left.\mathrm{E}\right)$, minerals $(\mathrm{Ca}, \mathrm{Mg}, \mathrm{Zn}$ and $\mathrm{Fe})$ and antioxidant substances which prevent the formation of cancer causing agents (Beecher, 1994). Broccoli contains a higher rate of sulforaphane that prevents Helicobacter pylori which are responsible for stomach cancer (Fahey et al., 2002). Nitrogen plays an important role in broccoli production and broccoli is highly dependent on $\mathrm{N}$ fertilization to achieve a good yield (Babik and Elkner, 2002). At present, different sources of $\mathrm{N}$ fertilizer are available in the market which may improve fertilizer use efficiency. Among these, USG is used by the farmers for upland vegetable crops like tomato, cabbage, broccoli, papaya, banana etc (Hussain et al., 2003; Nazrul et al., 2006). Total yield of broccoli is greatly influenced by the different doses of nitrogenous fertilizer (Bélec et al., 2001). Zaman et al. (1993) reported that $\mathrm{N}$ is an important plant nutrient and is the most limiting one due to its high mobility and different types of losses. To control such losses, USG application may be a good practice to minimize production cost as well as to increase $\mathrm{N}$ use efficiency, yield and quality of the crop.

On the other hand, leaf greenness is closely related to chlorophyll contents which is related to leaf $\mathrm{N}$ and the SPAD values- that is proportional to the chlorophyll content of leaves (Kapotis et al., 2003). Yoldas et al. (2008) reported that application of $\mathrm{N}$ increased $\mathrm{N}, \mathrm{P}, \mathrm{K}$ and $\mathrm{Fe}$ concentrations in broccoli head. Evaraarts and Willigen (1999) found that band placement of $\mathrm{N}$ influenced $\mathrm{N}$ uptake positively. The increase rate of $\mathrm{N}$ fertilizer induces increase of nitrate content in plant tissue of broccoli (Zebarth et al., 1995). As nitrogen plays a major role in agriculture and is also responsible for a number of environmental problems, nitrogen management is indispensable for maximizing broccoli yield and minimizing $\mathrm{N}$ loss and cultivation cost. Therefore, it is essential to evaluate the different forms of $\mathrm{N}$ and levels of USG and PU application for sustainable crop cultivation. To attain this goal the present study was undertaken to verify the effectiveness of USG and PU on the yield and quality of broccoli, to assess the comparative performance of USG and prilled urea on nutrient uptake and N use efficiency and to evaluate the effect of USG and PU on post-harvest nutrient status in Shallow Red-Brown Terrace Soil under Madhupur Tract (AEZ-28).

\section{Materials and Methods}

A field experiment was conducted at Bangabandhu Sheikh Mujibur Rahman Agricultural University during rabi season of 2012 - 2013. The soil of the experimental field belongs to Salna series representing the Shallow Red-Brown 
Terrace which falls under the order Inceptisols (FAO, 1988) representing Madhupur Tract (AEZ-28). Before setting up of the experiment, soil samples were collected from the experimental plots and different physico-chemical properties were analyzed as presented in Table $1 \mathrm{a}$ and $1 \mathrm{~b}$.

Table 1a. Physical properties of initial soil of the experimental plot

\begin{tabular}{lc}
\hline \multicolumn{1}{c|}{$\begin{array}{c}\text { Soil properties }(0-15 \mathrm{~cm} \text { soil } \\
\text { depth) }\end{array}$} & Analytical value \\
\hline Particle size distribution of soil: & \\
Sand (\%) & 17.8 \\
Silt (\%) & 45.6 \\
Clay (\%) & 36.6 \\
Texture & Silty clay loam \\
Bulk density $\left(\mathrm{g} \mathrm{cm}^{-3}\right)$ & 1.34 \\
Particle density $\left(\mathrm{g} \mathrm{cm}^{-3}\right)$ & 2.61 \\
Porosity $(\%)$ & 47.47 \\
Field capacity $(\%)$ & 28.67 \\
\hline
\end{tabular}

Table 1b. Chemical properties of initial soil of the experimental plot

\begin{tabular}{c|c|c|c|c|c|c|c|c}
\hline $\begin{array}{c}\text { Soil properties } \\
\begin{array}{c}0-15 \mathrm{~cm} \text { soil } \\
\text { depth) }\end{array}\end{array}$ & $\begin{array}{c}\text { Soil } \\
\mathrm{pH}\end{array}$ & $\begin{array}{c}\text { Organic } \\
\text { carbon }\end{array}$ & $\begin{array}{c}\text { Total } \\
\mathrm{N}\end{array}$ & $\begin{array}{c}\text { Exchangeable } \\
\mathrm{K}\end{array}$ & $\mathrm{CEC}$ & $\begin{array}{c}\text { Available } \\
\mathrm{P}\end{array}$ & $\begin{array}{c}\text { Available } \\
\mathrm{S}\end{array}$ & $\begin{array}{c}\text { Available } \\
\mathrm{B}\end{array}$ \\
\hline $\begin{array}{l}\text { Analytical } \\
\text { value }\end{array}$ & 5.97 & 0.96 & 0.10 & 0.32 & 12.67 & 14.18 & 13.78 & 0.21 \\
\hline
\end{tabular}

The experiment was laid out in a randomized complete block design with three replications having 5 treatments comprised of different levels of USG and PU as$\mathrm{T}_{1}$ : Control $(0 \mathrm{~kg} \mathrm{~N}), \mathrm{T}_{2}: \mathrm{USG} \mathrm{N}_{140}\left(140 \mathrm{~kg} \mathrm{~N}\right.$ as USG), $\mathrm{T}_{3}$ : USG-N ${ }_{160}(160 \mathrm{~kg} \mathrm{~N}$ as USG), $\mathrm{T}_{4}$ : USG- $\mathrm{N}_{180}\left(180 \mathrm{~kg} \mathrm{~N}\right.$ as USG) and $\mathrm{T}_{5}$ : $\mathrm{PU}-\mathrm{N}_{180}(180 \mathrm{~kg} \mathrm{~N}$ as $\mathrm{PU})$. Besides these, a blanket dose of nutrients@ $53 \mathrm{~kg} \mathrm{P}, 83 \mathrm{~kg} \mathrm{~K}, 20 \mathrm{~kg} \mathrm{~S}, 2.0 \mathrm{~kg}$ $\mathrm{Zn}, 1 \mathrm{~kg} \mathrm{~B}$ and $0.8 \mathrm{~kg} \mathrm{Mo} \mathrm{ha}{ }^{-1}$ in the forms of TSP, MoP, gypsum, boric acid, zinc oxide and sodium molybdate, respectively were applied mostly on the basis of initial soil test value following FRG, 2012 to all plots except the control. Nitrogen was applied as per treatment in two forms as USG and PU. "Premium Crop" a high yielding variety of broccoli (Brassica oleracea var. italica L.) collected from Taki seed company, Japan was used as a test crop. The unit plot size was $2.4 \mathrm{~m} \times 2.7 \mathrm{~m}\left(6.48 \mathrm{~m}^{2}\right)$ having plot to plot and block to block distances 
$0.75 \mathrm{~m}$ and $1.0 \mathrm{~m}$, respectively. After proper land preparation, 25-day-old seedlings were transplanted in lines on November 20, 2012 maintaining a row to row and plant to plant distance $0.60 \mathrm{~m}$ and $0.45 \mathrm{~m}$, respectively. Each plot was irrigated uniformly at every alternate day by watering can to bring the soil moisture at desired level. Weeding was done twice before first and second top dress. Earthing up was done to make a continuous line of ridges and furrows. For the establishment of crop, furrow irrigation was given at an interval of 7 days. MoP 50\% and all other fertilizers except PU and USG were applied as broadcasting and incorporated in soil during final land preparation. Prilled urea was top-dressed in two equal splits at 15 and 35 DAT in a ring method. At 15 DAT, USG was placed at 7-8 cm below the surface and $9-10 \mathrm{~cm}$ apart from broccoli plant. The remaining $50 \% \mathrm{MoP}$ was top-dressed at $15 \mathrm{DAT}$ followed by irrigation. Harvesting was started on $25^{\text {th }}$ January and continued up to $5^{\text {th }}$ February, 2013. Data on yield and other parameters were collected as outlined by Liu et al. (1993). Initial and post-harvest soil samples were collected and analyzed for both physical and chemical properties. Plant samples were also collected and analyzed for N, P, K, S and B contents. SPAD reading using the instrument Minolta SPAD-502 meter were recorded at 5 days interval after the application of USG and PU. SPAD readings were taken on the tip of the leaf along with the midrib (mid-point) of the three youngest but fully expanded leaves of five randomly selected plants. Fifteen leaves were measured at random from each plot and a mean SPAD value was calculated according to Costa et al. (2003). Post-harvest soil analysis was done to assess soil nutrient status. Total N of soil was determined following the micro-Kjeldahl method according to Jackson et al. (1973). Available P was determined following the sodium bicarbonate extraction using Colorimetric method (Olsen et al., 1954). Exchangeable potassium of soil was determined from ammonium acetate (1N $\mathrm{NH}_{4} \mathrm{OAC}$ ) extract as described by Jackson (1973) using flame-photometer. Available sulphur in soil was determined by extracting the samples with $\mathrm{CaCl}_{2}$ $(0.15 \%)$ solution (Page et al., 1982) using spectrophotometer at $420 \mathrm{~nm}$ wave length followed by turbidimetrical method. Total B content was measured by colorimetric method (Hunter, 1980) measuring concentration using double beam spectrophotometer. (Model no. 200-20, Hitachi, Japan) at $555 \mathrm{~nm}$ wave length.

Ascorbic acid (vitamin C) was determined by the Iodate method described by Samotus et al. (1982) using the formula as stated below:

$$
\text { Ascorbic acid (mg/100g FW) }=\frac{f \times V_{1} \times V_{2} \times 100}{W \times V_{13}}
$$

Where,

$$
\begin{aligned}
& \mathrm{V}_{2}=\text { Total volume of blended sample }(100 \mathrm{ml}) \\
& \mathrm{V}_{3}=\text { Volume of sample extract taken }(5 \mathrm{ml})
\end{aligned}
$$




$$
\begin{aligned}
& \mathrm{W}=\text { Weight of fresh head sample }(20 \mathrm{~g}) \\
& \mathrm{V}_{1}=\text { Titrated volume of } \mathrm{KIO}_{3}(\mathrm{ml})
\end{aligned}
$$

Chlorophyll $\mathrm{a}$, Chlorophyll $\mathrm{b}$ and $\beta$-carotene were determined following acetonehaxen method as stated by Masayasu and Yamashita (1992). The chlorophyll a, chlorophyll $b$ and $\beta$-carotene contents were estimated using the formula as follows:

$$
\begin{aligned}
& \text { Chlorophyll a }(\mathrm{mg} / 100 \mathrm{ml})=0.999 \mathrm{~A}_{663}-0.0989 \mathrm{~A}_{645} \\
& \text { Chlorophyll b }(\mathrm{mg} / 100 \mathrm{ml})=0.328 \mathrm{~A}_{663}+1.77 \mathrm{~A}_{645} \\
& \beta \text {-carotene }(\mathrm{mg} / 100 \mathrm{ml})=0.216 \mathrm{~A}_{663}-1.22 \mathrm{~A}_{645}-0.304 \mathrm{~A}_{505}+ \\
& 0.452 \mathrm{~A}_{453}
\end{aligned}
$$

* $\mathrm{A}_{663}, \mathrm{~A}_{645}, \mathrm{~A}_{505}, \mathrm{~A}_{453}$ are absorbance at $663 \mathrm{~nm}, 645 \mathrm{~nm}, 505 \mathrm{~nm}$ and $453 \mathrm{~nm}$, respectively.

Plant biomass was estimated by oven dry method. Samples were dried at $65^{\circ}-70^{\circ}$ $\mathrm{C}$ for 72 hours and weighted. The biomasses per plant, per plot and per hectare were calculated by the following formula:

a). Biomass per plant $(\mathrm{g})=\frac{\text { (Total above ground biological yield of } 10 \text { plants }(\mathrm{g})}{100}$

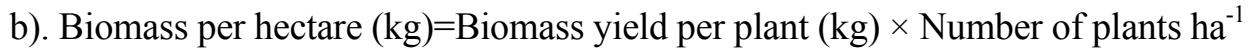

To evaluate leaf nutrient content, leaf samples were collected from matured leaf of five randomly selected plants at harvesting stage which were then oven dried and ground for analyses. To estimate the head quality, samples were collected from the head of five randomly selected plants from each treatment. Collected samples were analyzed for vitamin-C, $\beta$-carotene and chlorophyll content. Plant nitrogen in leaf, stem and head samples were determined following the MicroKjeldahl method and phosphorus was determined after digestion with $\mathrm{HNO}_{3}$ and $\mathrm{HClO}_{4}$ mixture followed by ammonium vana-molybdate method colorimetrically with the help of a spectrophotometer at $660 \mathrm{~nm}$ wavelength. Potassium contents were determined directly with the help of flame photometer after digesting the samples with di-acid mixture and sulphur content was measured by adding $6 \mathrm{~N}$ $\mathrm{HCl}$ plant extract with $\mathrm{BaCl}_{2}$ outlined by Black, 1965 .

Nutrient uptake from the soil was calculated by using the formula:

Nutrient uptake $\left(\mathrm{kg} \mathrm{ha}^{-1}\right)=\frac{\left(\% \text { Nutrient } \times \mathrm{Y}\left(\mathrm{kg} \mathrm{ha}^{-1}\right)\right.}{100}$

Here,

$\%$ Nutrient $=$ Average nutrient content $(\%)$ of plant or head biomass

$\mathrm{Y}\left(\mathrm{kg} \mathrm{ha}^{-1}\right)=$ Total dry matter production of plant or head biomass 
Nitrogen use efficiency (NUE) was determined by the equation stated by Craswell and Godwin (1984):

Nitrogen use efficiency $(\mathrm{NUE})=\frac{(\mathrm{N} \text { uptake } \mathrm{F}-\mathrm{N} \text { uptake } \mathrm{C})}{\text { Fertilizer } \mathrm{N} \text { applied }} \times 100$

Where,

$\mathrm{F}$ and $\mathrm{C}$ denote fertilized crop and unfertilized (control), respectively.

The collected data were then compiled and statistical analyses were done by using the statistical package, MSTATC. Mean separation was done by DMRT at $5 \%$ level of probability. Computation and preparation of graphs were made using Microsoft Excel 2003 program.

\section{Results and Discussion}

\section{Effect of USG and PU on yield and yield attributes of broccoli}

\section{Plant height}

Plant height was significantly influenced due to different forms and levels of nitrogen and it was increased with increasing rate of $\mathrm{N}$ fertilizer (Table 2). At harvest, the highest plant height $(67.10 \mathrm{~cm})$ was recorded from USG-N ${ }_{180}$ which was statistically identical with USG-N $\mathrm{N}_{160}(65.28 \mathrm{~cm})$ and $\mathrm{PU} \mathrm{N}_{180}(64.77 \mathrm{~cm})$ (Table 2). This phenomenon might be due to continuous supply, higher availability and uptake rate of $\mathrm{N}$ from USG for its longer retention in soil than that of PU, which is vulnerable to loss in many ways. The minimum plant height $(44.98 \mathrm{~cm})$ was recorded from $\mathrm{N}$-control. These results are similar to the findings of Hala and Nadia (2009) who observed the highest plant height and number of leaves plant ${ }^{-1}$ with the minimum dose of $\mathrm{N}$ along with $\mathrm{P}$ and $\mathrm{K}$.

\section{Number of leaves plant ${ }^{-1}$}

Number of leaves plant ${ }^{-1}$ significantly increased due to different forms and levels of $\mathrm{N}$ (Table 2). The maximum number of leaves $\left(14.30\right.$ plant $\left.^{-1}\right)$ was recorded with USG- $\mathrm{N}_{180}$ followed by USG-N $\mathrm{N}_{160}\left(14.10\right.$ plant $\left.^{-1}\right)$. The minimum number of leaves (11.63 plant $\left.^{-1}\right)$ was obtained from the control. These results are in accordance with the findings of Ouda and Mahadeen (2008). Such effect of N on number of leaves plant ${ }^{-1}$ was also reported by Nasreen et al. (1992) and Masson et al. (1991). Thakur et al. (1991) reported that increasing rate of $\mathrm{N}$ application delayed head maturity and increased the number of leaves plant ${ }^{-1}$, leaf area, gross plant weight, stalk length, dry matter content and head yield of cauliflower.

\section{Head length}

The highest head length $(14.07 \mathrm{~cm})$ was recorded from USG-N ${ }_{140}$ followed by USG-N ${ }_{160}$ which was statistically identical with PU-N ${ }_{180}$ and USG-N ${ }_{180}$ (Table 2) 
but significantly higher over N-control. The head length recorded in PU-N $\mathrm{N}_{180}$ was higher than that of USG- $\mathrm{N}_{180}$ which might be due to lower flow of translocates to cell development in comparison to cell elongation. The lowest head length (10.4 $\mathrm{cm}$ ) was observed in N-control. Chao-Jiong et al. (2010) also reported similar result in case of broccoli.

\section{Head diameter}

Head diameter was significantly affected by the different levels of $\mathrm{N}$ where the maximum head diameter $(19.47 \mathrm{~cm})$ was recorded from $\mathrm{USG}_{160}$, which was statistically similar to USG-N $\mathrm{N}_{180}(18.67 \mathrm{~cm})$ but significantly higher than all other treatments (Table 2). This might be due to continuous and balanced supply of assimilates from leaf to floret. The lowest diameter $(9.83 \mathrm{~cm})$ was recorded from $\mathrm{N}$-control. This finding is in agreement with the findings of Yoldas et al. (2008) who reported that increased $\mathrm{N}$ rates significantly increased yield, average weight of main and lateral heads, and the diameter in broccoli compared to control.

\section{Head weight}

Individual head weight was also significantly influenced by the application of different $\mathrm{N}$ levels. It was increased with increasing level of $\mathrm{N}$ fertilizer upto 160 $\mathrm{kg} \mathrm{N} \mathrm{ha}^{-1}$ where the highest head weight (364.3 $\mathrm{g} \mathrm{plant}^{-1}$ ) was obtained from USG- $\mathrm{N}_{160}$ followed by USG-N $\mathrm{N}_{180}$ which was statistically identical with $\mathrm{PU}_{180}$ (Table 2). This might be due to maximum translocation of carbohydrate from leaf to head which increased size, shape and head compactness with an optimum vegetative growth. The minimum head weight $\left(131.8 \mathrm{~g}\right.$ plant $\left.^{-1}\right)$ was recorded from N-control. Similar results were obtained by Chao-Jiong (2010) in broccoli. Rickard (2008) reported that $\mathrm{N}$ had a curvilinear effect on marketable yield and an increase was seen up to application of $165 \mathrm{~kg} \mathrm{~N} \mathrm{ha}^{-1}$ which may justify the present findings.

Table 2. Effect of different forms and levels of $\mathrm{N}$-fertilizer on yield components of broccoli

\begin{tabular}{l|c|c|c|c|c}
\hline Treatment & $\begin{array}{c}\text { Plant height } \\
(\mathrm{cm})\end{array}$ & $\begin{array}{c}\text { Number of } \\
\text { leaves plant }^{-1}\end{array}$ & $\begin{array}{c}\text { Head length } \\
(\mathrm{cm})\end{array}$ & $\begin{array}{c}\text { Head } \\
\text { diameter } \\
(\mathrm{cm})\end{array}$ & $\begin{array}{c}\text { Head weight } \\
\left(\mathrm{g} \mathrm{plant}^{-1}\right)\end{array}$ \\
\hline Control & $51.64 \mathrm{c}$ & $11.63 \mathrm{~b}$ & $10.40 \mathrm{~b}$ & $9.83 \mathrm{~d}$ & $131.8 \mathrm{c}$ \\
USG-N $_{140}$ & $62.14 \mathrm{~b}$ & $13.56 \mathrm{a}$ & $14.07 \mathrm{a}$ & $17.43 \mathrm{bc}$ & $316.3 \mathrm{~b}$ \\
USG-N $_{160}$ & $65.28 \mathrm{ab}$ & $14.10 \mathrm{a}$ & $14.00 \mathrm{a}$ & $19.47 \mathrm{a}$ & $364.3 \mathrm{a}$ \\
USG-N $_{180}$ & $67.10 \mathrm{a}$ & $14.30 \mathrm{a}$ & $13.07 \mathrm{a}$ & $18.67 \mathrm{ab}$ & $349.0 \mathrm{ab}$ \\
PU-N $_{180}$ & $64.77 \mathrm{ab}$ & $13.93 \mathrm{a}$ & $13.47 \mathrm{a}$ & $17.20 \mathrm{c}$ & $325.3 \mathrm{ab}$ \\
\hline $\mathrm{CV}(\%)$ & 2.45 & 4.41 & 8.58 & 4.04 & 6.88 \\
SE $( \pm 0.05)$ & 0.8809 & 0.3440 & 0.6439 & 0.3851 & 11.82 \\
\hline
\end{tabular}

Means followed by uncommon letters are statistically different from each other at $5 \%$ level of provability by DMRT. 


\section{Head yield}

The head yield of broccoli was significantly influenced by the different forms and levels of $\mathrm{N}$. It was increased with increasing rate of $\mathrm{N}$ up to USG-N $\mathrm{N}_{160} \mathrm{~kg} \mathrm{ha}^{-1}$ and then declined. The highest head yield (13.49 ton $\left.\mathrm{ha}^{-1}\right)$ was obtained with USG-N $_{160}$ followed by USG-N ${ }_{180}$ (12.93 ton ha ${ }^{-1}$ ) (Fig.1). Prilled urea treated plot (PU-N ${ }_{180}$ ) gave 12.05 ton ha $^{-1}$ head yield which was statistically identical with USG-N $\mathrm{N}_{140}$. This might be due to maximum translocation of carbohydrate from leaf to head that increased size and head compactness optimizing vegetative growth for higher $\mathrm{N}$ supply. USG-N $\mathrm{N}_{180}$ also produced more yield than that of PU$\mathrm{N}_{180}$ which indicated the superiority of USG over PU. The minimum head yield (4.88 ton ha ${ }^{-1}$ ) was recorded from N-control. This result is in agreement with the findings of Greenwood et al. (1980) where the maximum broccoli yield was obtained with the recommended doses from $175-252 \mathrm{~kg} \mathrm{~N}^{-1}$. Zebarth et al. (1995) found that marketable yield of broccoli increased with increasing $\mathrm{N}$ rate in a curvilinear pattern. Similar results were reported by Goodlass et al. (1997) and Chao-Jiong (2010) in broccoli. The low crop yield from the control treatment is due to the insufficient supply of $\mathrm{N}$ in plants, leading to limit the carbon assimilation, resulting in reduction of plant productivity (Lawlor, 2002).

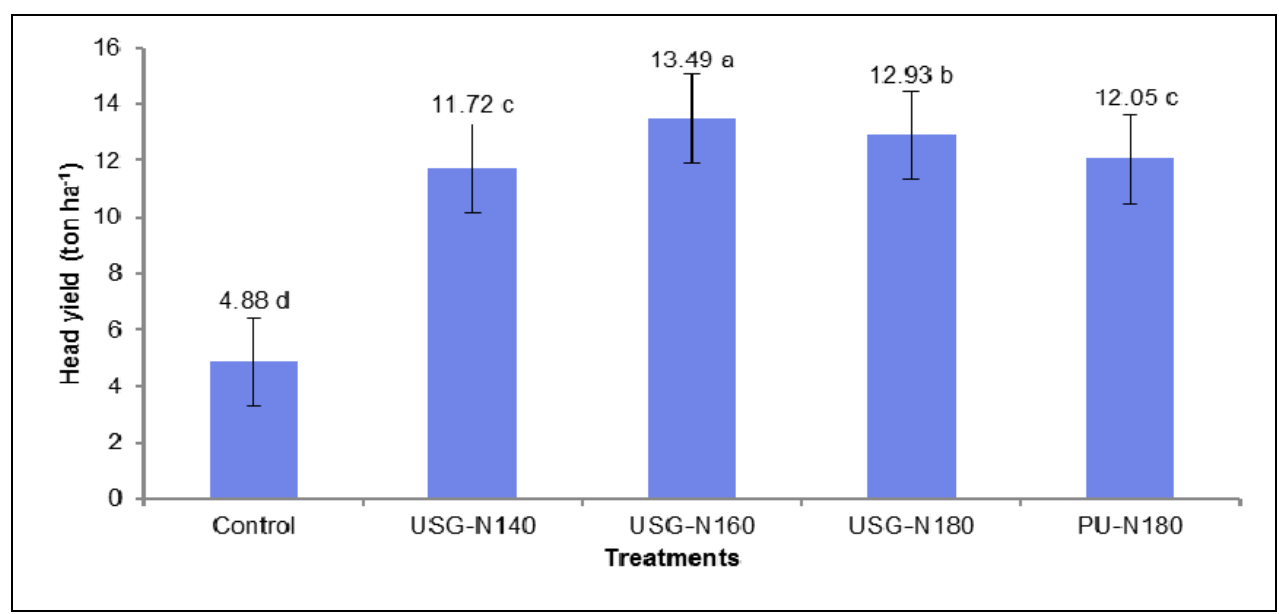

Fig. 1. Effect of different forms and levels of $\mathbf{N}$-fertilizer on head yield of broccoli (Vertical bar showing the SE; CV: $6.88 \%$ ).

\section{Effect of USG and PU on quality attributes of broccoli}

\section{SPAD value}

Results on SPAD (Soil Plant Analysis Development) value was recorded to determine the leaf greenness and to compare leaf chlorophyll content as affected by different forms and levels of urea $\mathrm{N}$ and presented in Table 3. At initial stage up to 35 DAT, no significant variation was found with the SPAD values of the broccoli leaf (Table 3) although it was slightly higher in PU-N ${ }_{180}$. However, at 
later stages from 40 DAT, a significant variation was observed among the treatments and it was increased with increasing levels of urea $\mathrm{N}$. At these stages the highest SPAD values were recorded with USG-N ${ }_{180}$ which was slightly higher than that of PU- $\mathrm{N}_{180}$. The maximum increase of SPAD values $(11.59 \%)$ was noted at 60 DAT over 25 DAT for the control. But it was 25.03 and $18.27 \%$ at 60 DAT over 25 DAT for USG-N $\mathrm{N}_{180}$ and USG-N $\mathrm{N}_{180}$, respectively. Perhaps this phenomenon was due to rapid availability of $\mathrm{N}$ at initial stage as it was closer and adjacent to the root zone in case of PU, but at later stages availability of $\mathrm{N}$ from USG increased over time and ensured a continuous supply upto harvest (70 DAT). On the other hand, supply of $\mathrm{N}$ from PU became limiting at later stages. Maximum SPAD values were recorded at 60 DAT and then decreased slightly. At 60 DAT, the maximum SPAD value (74.73) was recorded from USG-N ${ }_{180}$ followed by USG-N ${ }_{160}(73.10)$ and PU-N 180 (Table 3). However, at harvest (70 DAT) the highest SPAD value (73.93) was recorded with USG-N $\mathrm{N}_{180}$ followed by USG- $\mathrm{N}_{160}$ (72.23) but it was 72.07 for PU- $\mathrm{N}_{180}$ treatment (Table 3). Perhaps this was due to higher $\mathrm{N}$ content in leaf. The minimum SPAD value was recorded in N-control. Similar results were also reported by Bullock and Anderson (1998), Kantety et al. (1996) and Wang et al. (2004). Varvel et al. (1997) demonstrated that $\mathrm{N}$ fertilizer significantly increased both corn grain yield and SPAD readings.

Table 3. SPAD values as affected by different forms and levels of $\mathbf{N}$-fertilizer at different days after transplanting

\begin{tabular}{l|c|c|c|c|c|c|c|c|c|c}
\hline Treatment & $\begin{array}{c}25 \\
\text { DAT }\end{array}$ & $\begin{array}{c}30 \\
\text { DAT }\end{array}$ & 35 DAT & 40 DAT & 45 DAT & $\begin{array}{c}50 \\
\text { DAT }\end{array}$ & $\begin{array}{c}55 \\
\text { DAT }\end{array}$ & $\begin{array}{c}60 \\
\text { DAT }\end{array}$ & $\begin{array}{c}65 \\
\text { DAT }\end{array}$ & $\begin{array}{c}70 \\
\text { DAT }\end{array}$ \\
\hline Control & 56.07 & 56.20 & 57.20 & $58.20 \mathrm{c}$ & $60.07 \mathrm{~b}$ & $60.30 \mathrm{~b}$ & $61.47 \mathrm{~b}$ & $62.57 \mathrm{~b}$ & $62.23 \mathrm{~b}$ & $62.30 \mathrm{~b}$ \\
USG-N $_{140}$ & 56.90 & 56.93 & 57.13 & $59.93 \mathrm{bc}$ & $66.40 \mathrm{a}$ & $68.63 \mathrm{a}$ & $71.67 \mathrm{a}$ & $72.27 \mathrm{a}$ & $71.70 \mathrm{a}$ & $71.50 \mathrm{a}$ \\
USG-N $_{160}$ & 59.27 & 59.57 & 60.53 & $64.47 \mathrm{ab}$ & $67.17 \mathrm{a}$ & $69.23 \mathrm{a}$ & $71.67 \mathrm{a}$ & $73.10 \mathrm{a}$ & $72.77 \mathrm{a}$ & $72.23 \mathrm{a}$ \\
USG-N $_{180}$ & 59.77 & 60.67 & 61.30 & $65.80 \mathrm{a}$ & $68.77 \mathrm{a}$ & $71.10 \mathrm{a}$ & $73.00 \mathrm{a}$ & $74.73 \mathrm{a}$ & $74.10 \mathrm{a}$ & $73.93 \mathrm{a}$ \\
PU-N $_{180}$ & 62.17 & 62.47 & 63.80 & $64.50 \mathrm{ab}$ & $67.33 \mathrm{a}$ & $70.53 \mathrm{a}$ & $72.97 \mathrm{a}$ & $73.53 \mathrm{a}$ & $72.37 \mathrm{a}$ & $72.07 \mathrm{a}$ \\
\hline $\mathrm{CV}(\%)$ & 4.82 & 6.18 & 3.94 & 3.82 & 3.43 & 3.33 & 2.19 & 3.56 & 3.59 & 4.02 \\
$\mathrm{SE}( \pm 0.05)$ & 1.642 & 2.121 & 1.360 & 1.380 & 1.306 & 1.306 & 0.8884 & 1.464 & 1.462 & 1.632 \\
\hline
\end{tabular}

Means followed by uncommon letters are statistically different from each other at $5 \%$ level of probability by DMRT

\section{Compactness coefficient}

The higher the head compactness the better the head quality of broccoli. Head compactness significantly increased with increasing levels of $\mathrm{N}$ and the highest compactness coefficient (18.91) was found from PU-N ${ }_{180}$ followed by USG- $\mathrm{N}_{160}$ (18.71) which were statistically similar to all other treatments except control with the lowest compactness coefficient (13.41) (Fig. 2). It was due to higher supply of translocates but lower cell elongation which might have caused maximum 
accumulation of assimilates as well as higher head compactness. This finding is in agreement with the result of Renata et al. (2005) in broccoli.

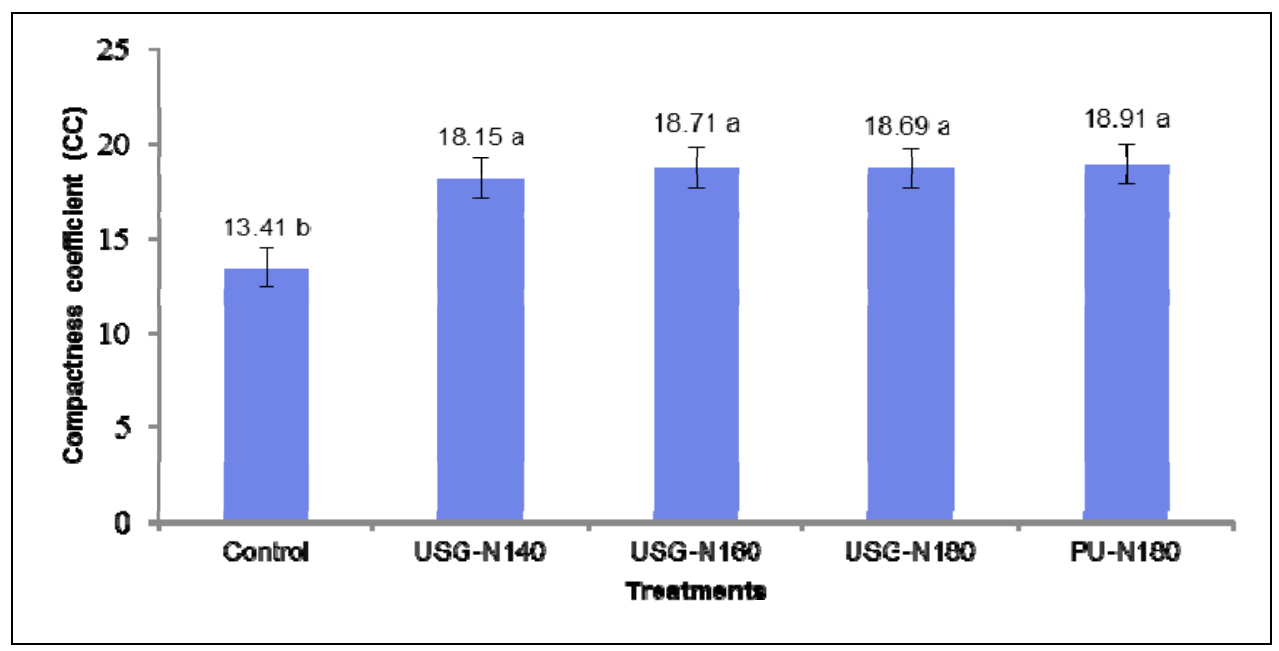

Fig. 2. Effect of different forms and levels of $\mathrm{N}$-fertilizer on compactness coefficient of broccoli head (Vertical bar showing the SE; CV: $7.53 \%$ ).

\section{Ascorbic acid and $\beta$-carotene content}

A significant difference was observed with ascorbic acid (Vitamin C) content.

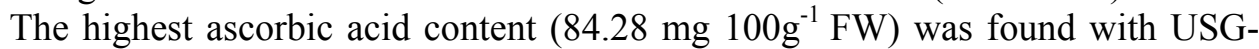
$\mathrm{N}_{140}$ which was followed by USG-N $\mathrm{N}_{160}\left(83.60 \mathrm{mg} 100 \mathrm{~g}^{-1} \mathrm{FW}\right)$ but identical with $\mathrm{N}$-control $\left(79.93 \mathrm{mg} 100 \mathrm{~g}^{-1} \mathrm{FW}\right)$. The lowest ascorbic acid content $(66.33 \mathrm{mg}$ $100 \mathrm{~g}^{-1} \mathrm{FW}$ ) was recorded with PU-N $\mathrm{N}_{180}$ (Table 4). This might be due to the higher nitrogen doses produced higher fresh but reduced dry matter content which resulted in less ascorbic acid. Karitonas (2001) reported that an increased level of $\mathrm{N}$ supply slightly reduced the vitamin C content from 83 to $73 \mathrm{mg} 100 \mathrm{~g}^{-1} \mathrm{FW}$ in broccoli flowers. Similar result was also reported by Chao-Jiong et al. (2010). Beta-carotene content was significantly influenced by different treatments and the highest $\beta$-carotene content was recorded with USG-N ${ }_{160}(0.384 \mathrm{mg} / 100 \mathrm{~g} \mathrm{FW})$ followed by USG-N $\mathrm{N}_{180}\left(0.373 \mathrm{mg} 100 \mathrm{~g}^{-1} \mathrm{FW}\right)$ but statistically identical with PU$\mathrm{N}_{180}$ and USG-N $\mathrm{N}_{140}$ (Table 4). The minimum and significantly different $\beta$ carotene content $\left(0.312 \mathrm{mg} 100 \mathrm{~g}^{-1} \mathrm{FW}\right)$ was recorded with control treatment.

\section{Chlorophyll-a and chlorophyll-b content}

Chlorophyll-a content was significantly higher at higher level of USG and 0.738 mg $100 \mathrm{~g}^{-1} \mathrm{FW}$ was recorded with USG-N ${ }_{180}$ which was statistically identical with

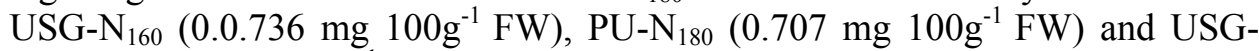
$\mathrm{N}_{140}\left(0.685 \mathrm{mg} 100 \mathrm{~g}^{-1} \mathrm{FW}\right)$ (Table 4). Statistically the lowest chlorophyll-a content $\left(0.671 \mathrm{mg} 100 \mathrm{~g}^{-1} \mathrm{FW}\right)$ was noted with control treatment. Chlorophyll-b 
content was also higher at higher levels of USG and the highest chlorophyll-b content $\left(1.1154 \mathrm{mg} 100 \mathrm{~g}^{-1} \mathrm{FW}\right)$ was observed with USG-N $\mathrm{N}_{180}$, which was statistically identical with USG-N $\mathrm{N}_{160}$. However, the statistically lowest

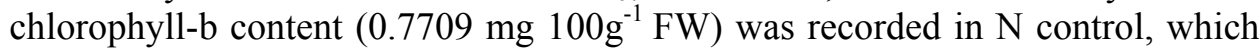
was significantly lower than USG treated plant but identical to PU-N ${ }_{180}$ (Table 4). The plants under PU-N $\mathrm{N}_{180}$ always contained lower chlorophyll-b than that of USG- $\mathrm{N}_{180}$. Ouda and Mahadeen (2008) reported that head number per plant, head diameter and chlorophyll content were higher when a combination of organic and inorganic fertilizers was added compared with their individual addition.

Table 4. Effect of different forms and levels of $\mathbf{N}$-fertilizer on the head quality of broccoli

\begin{tabular}{|c|c|c|c|c|}
\hline Treatment & $\begin{array}{l}\text { Ascorbic acid } \\
\left(\mathrm{mg} 100 \mathrm{~g}^{-1} \mathrm{FW}\right)\end{array}$ & $\begin{array}{c}\beta \text {-carotene } \\
\left(\mathrm{mg} 100 \mathrm{~g}^{-1} \mathrm{FW}\right)\end{array}$ & $\begin{array}{l}\text { Chlorophyll-a } \\
\left(\mathrm{mg} 100 \mathrm{~g}^{-1} \mathrm{FW}\right)\end{array}$ & $\begin{array}{c}\text { Chlorophyll-b } \\
\text { (mg 100g-1 } \\
\text { FW) }\end{array}$ \\
\hline Control & $79.93 \mathrm{ab}$ & $0.312 \mathrm{~b}$ & $0.671 \mathrm{~b}$ & $0.7709 \mathrm{c}$ \\
\hline USG-N $_{140}$ & $84.28 \mathrm{a}$ & $0.346 \mathrm{ab}$ & $0.685 \mathrm{ab}$ & $0.9743 \mathrm{bc}$ \\
\hline USG-N $_{160}$ & $83.60 \mathrm{a}$ & $0.384 \mathrm{a}$ & $0.736 \mathrm{a}$ & $1.0359 \mathrm{ab}$ \\
\hline USG-N $_{180}$ & $75.10 \mathrm{~b}$ & $0.373 \mathrm{ab}$ & $0.738 \quad \mathrm{a}$ & $1.1154 \mathrm{a}$ \\
\hline PU-N 180 & $66.33 \mathrm{c}$ & $0.346 \mathrm{ab}$ & $0.707 \mathrm{ab}$ & $0.9813 \mathrm{bc}$ \\
\hline CV (\%) & 5.39 & 6.81 & 3.68 & 7.36 \\
\hline $\mathrm{SE}( \pm 0.05)$ & 2.420 & 0.01826 & 0.01826 & 0.03873 \\
\hline
\end{tabular}

Means followed by uncommon letters are statistically different from each other at $5 \%$ level of provability by DMRT

\section{Effect of USG and PU on nutrient uptake by broccoli}

\section{Nitrogen uptake}

Nitrogen uptake increased with the increasing levels of urea $\mathrm{N}$ and the highest $\mathrm{N}$ uptake $\left(273.65 \mathrm{~kg} \mathrm{ha}^{-1}\right)$ was found with USG-N 180 followed by USG-N ${ }_{160}(267.02$ $\left.\mathrm{kg} \mathrm{ha}^{-1}\right)$ and PU-N $\mathrm{N}_{180}$ showed the third highest $\mathrm{N}$ uptake $\left(235.70 \mathrm{~kg} \mathrm{ha}{ }^{-1}\right)$. However, the higher $\mathrm{N}$ uptake was found from USG treated plots as compared to PU (Table 5). This might be due to continuous supply, higher $\mathrm{N}$ retaining capacity in the soil and greater fertilizer-N recovery in case of USG than that of PU. The possible reason for higher uptake is that as USG placed at deeper zone the limited number of nitrifying bacteria present at the premise of USG and converts a limited portion of urea to $\mathrm{NO}_{3}^{-1}-\mathrm{N}$. Consequently, takes more time to convert whole USG to available $\mathrm{N}$ as compared to $\mathrm{PU}$ resulted in greater opportunity for plants to take up $\mathrm{N}$ from soil. This result is in agreement with the findings of Rashid et al. (1996). They reported that the use of $\mathrm{N}$ as USG was more effective than that of PU and they also stated that deep placement of USG was an effective means of increasing $\mathrm{N}$ use efficiency of rice as compared to the 
traditional split application of PU. Khalil et al. (2011), Zebarth et al. (1995) and Rickard (2008) also reported the similar findings.

\section{Nitrogen use efficiency}

From the study, it was found that the $\mathrm{N}$ use efficiency was increased with increasing levels of $\mathrm{N}$ upto USG- $\mathrm{N}_{160}(111.71 \%)$ and then decreased with the further increased rate of $\mathrm{N}$ fertilizer (Fig. 3). The lowest $\mathrm{N}$ use efficiency was found from PU-N ${ }_{180}(81.90 \%)$. Overall $\mathrm{N}$ use efficiency was higher with USG than that of PU. This result was more or less similar to that of the findings of Khalil et al. (2011). The apparent $\mathrm{N}$ recovery decreased with increasing rate of fertilizer $\mathrm{N}$ application for several vegetable crops (Greenwood and Draycott, 1988). Rashid et al. (1996) reported that the use of N as USG was more effective than that of PU and they also stated that the deep placement of USG was an effective means of increasing $\mathrm{N}$ use efficiency of rice as compared to the traditional split application of PU. Zebarth et al. (1995) reported that the apparent fertilizer- $\mathrm{N}$ recovery in the aboveground portion of the plant decreased linearly from between 46 and $93 \%$ at a $\mathrm{N}$ rate of $125 \mathrm{~kg} \mathrm{~N}$ ha-' to between 20 and $45 \%$ at a $\mathrm{N}$ rate of $625 \mathrm{~kg} \mathrm{~N}^{-1}$. Letey et al. (1983) reported $76 \% \mathrm{~N}$ use efficiency and Thompson et al. (2002) found 87.4, 69.0 and $81.3 \%$, N use efficiency with 13.0, 18.9 and 11.5 ton yield $\mathrm{ha}^{-1}$ of broccoli for different years. Accordingly, $\mathrm{N}$ use efficiency (NUE) of broccoli decreased with increasing amount of fertilizer (Riley and Vagen, 2003; Tremblay and Beaudet, 2006). Lower N rates affected crop growth and reduced $\mathrm{N}$ uptake while the higher $\mathrm{N}$ rates caused losses through the root zone. Another fact to the higher NUE is the less root disturbance, since there was no lateral dressing in case of USG and it was placed only once at a cropping season. A larger root system, and possibly a stronger plant, could have contributed to better $\mathrm{N}$ uptake by USG treated plots.

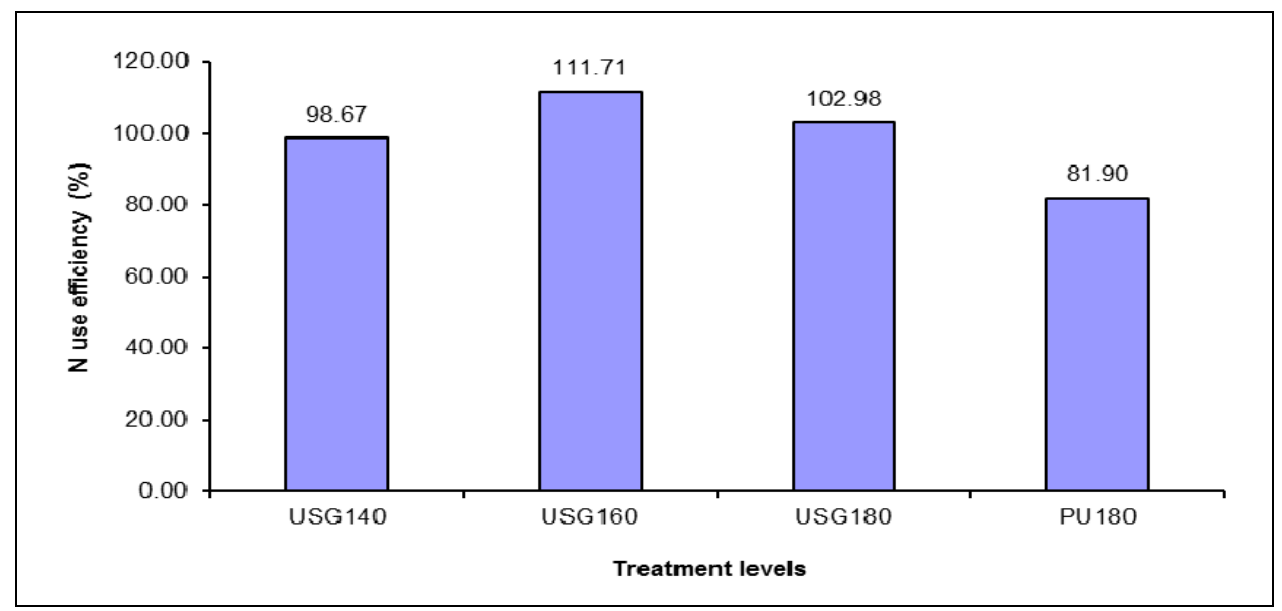

Fig. 3. Effect of different forms and levels of $\mathrm{N}$-fertilizer on $\mathrm{N}$ use efficiency of broccoli. 
Table 5. Effect of different forms and levels of $\mathrm{N}$-fertilizer on N, P, K and S uptake

\begin{tabular}{l|c|c|c|c}
\multicolumn{1}{c}{ by broatment } & $\begin{array}{c}\text { N uptake } \\
\left(\mathrm{kgha}^{-1}\right)\end{array}$ & $\begin{array}{c}\text { P uptake } \\
\left(\mathrm{kg} \mathrm{ha}^{-1}\right)\end{array}$ & $\begin{array}{c}\text { K uptake } \\
\left(\mathrm{kg} \mathrm{ha}^{-1}\right)\end{array}$ & $\begin{array}{c}\text { S uptake } \\
\left(\mathrm{kg} \mathrm{ha}^{-1}\right)\end{array}$ \\
\hline N-control & $88.28 \mathrm{c}$ & $8.03 \mathrm{c}$ & $73.17 \mathrm{c}$ & $0.48 \mathrm{~d}$ \\
USG-N $_{140}$ & $226.42 \mathrm{~b}$ & $25.22 \mathrm{~b}$ & $186.09 \mathrm{~b}$ & $1.48 \mathrm{c}$ \\
USG-N $_{160}$ & $267.02 \mathrm{a}$ & $27.37 \mathrm{a}$ & $197.20 \mathrm{a}$ & $1.85 \mathrm{a}$ \\
USG-N $_{180}$ & $273.65 \mathrm{a}$ & $29.08 \mathrm{a}$ & $207.19 \mathrm{a}$ & $1.77 \mathrm{a}$ \\
PU-N & & $25.54 \mathrm{~b}$ & $192.66 \mathrm{~b}$ & $1.66 \mathrm{~b}$ \\
\hline $\mathrm{CV}(\%)$ & $235.70 \mathrm{~b}$ & 5.46 & 3.88 & 6.23 \\
SE $( \pm 0.05)$ & 5.575 & 0.7230 & 3.836 & 0.05164 \\
\hline
\end{tabular}

Means followed by uncommon letters are statistically different from each other at $5 \%$ level of provability by DMRT

\section{Phosphorus and potassium uptake}

Phosphorus uptake increased significantly with increasing levels of urea $\mathrm{N}$ in the form of USG and the highest $29.08 \mathrm{~kg} \mathrm{ha}^{-1}$ was found with USG-N ${ }_{180}$ which was followed by USG-N $\mathrm{N}_{160}\left(27.37 \mathrm{~kg} \mathrm{ha}^{-1}\right)$, but this was statistically identical (Table 5). Third highest $P$ uptake $25.54 \mathrm{~kg} \mathrm{ha}^{-1}$ was with $\mathrm{PU}-\mathrm{N}_{180}$ and significantly identical with USG-N $\mathrm{N}_{140}$. USG performed better than PU. The highest K uptake $\left(207.19 \mathrm{~kg} \mathrm{ha}^{-1}\right)$ was noted with USG-N ${ }_{180}$ which was statistically identical with USG-N $_{160}\left(197.20 \mathrm{~kg} \mathrm{ha}^{-1}\right)$. Significantly lower K uptake was observed with PU$\mathrm{N}_{180}$ (Table 5). This result was supported by Yoldas et al. (2008). They reported that the application of $\mathrm{N}$ increased $\mathrm{N}, \mathrm{P}, \mathrm{K}$ and Fe concentrations in broccoli head. Similar results were also reported by Abdelrazzag (2002) and Magnusson (2002) on several vegetable crops. The synergistic effect between $\mathrm{N}$ and $\mathrm{K}$ resulted in higher $\mathrm{K}$ uptake with increasing levels of $\mathrm{N}$.

\section{Sulphur uptake}

Sulphur uptake also increased significantly with increasing levels of urea $\mathrm{N}$ upto USG- $\mathrm{N}_{160}$ and then it was decreased and showed a curvilinear fashion (Table 5). The highest $\mathrm{S}$ uptake $1.85 \mathrm{~kg} \mathrm{ha}^{-1}$ was noted from USG-N ${ }_{160}$ followed by USG$\mathrm{N}_{180}\left(1.77 \mathrm{~kg} \mathrm{ha}^{-1}\right)$ but statistically identical. A lower S uptake $\left(1.66 \mathrm{~kg} \mathrm{ha}^{-1}\right)$ was obtained with PU-N $\mathrm{N}_{180}$ than that of USG-N $\mathrm{N}_{180}$. Therefore, it was observed that a higher uptake of S from USG treated plots than that of PU (Table 5). This is due to continuous supply, higher S use efficiency and greater fertilizer S recovery in case of USG.

\section{Effect of USG and PU on post-harvest soil nutrient status of broccoli field}

Statistically significant variation was observed for post harvest nutrient status of soil due to different forms and levels of $\mathrm{N}$ (Table 6). The highest $\mathrm{N}$ content 
$(0.101 \%)$ was found in USG-N $\mathrm{N}_{180}$ treated plant which was followed by PU-N $\mathrm{N}_{180}$ $(0.099 \%)$, but statistically identical with each other (Table 6). The lowest $\mathrm{N}$ content $(0.077 \%)$ was found in N-control, which was significantly lower than USG- $\mathrm{N}_{180}$ and PU-N $\mathrm{N}_{180}$. This finding was supported by Evaraarts and Willigen (1999) who reported that the amount of mineral $\mathrm{N}$ in the soil at harvest generally increased with increasing amounts of $\mathrm{N}$ applied. Result revealed that USG addition exhibited more residual effect on soil-N content than that of PU. Phosphorus content did not follow any pattern although the highest $\mathrm{P}$ content $(17.59 \mu \mathrm{g} g-1)$ was found in control plot (Table 6). A significant variation was observed in post harvest soil $\mathrm{K}$ content and the highest $\mathrm{K}$ content $(0.188$ $\mathrm{me} / 100 \mathrm{~g}$ ) was recorded from control which was followed by USG-N $\mathrm{N}_{140}>$ USG$\mathrm{N}_{160}>$ PU-N $\mathrm{N}_{180}>$ USG-N $\mathrm{N}_{180}$, respectively (Table 6). The lowest $\mathrm{K}$ content $(0.138$ $\mathrm{me} / 100 \mathrm{~g}$ ) was found with USG-N ${ }_{180}$. It might be due to higher uptake and removal of K by the crop. Similarly a significant variation was observed in post harvest soil $\mathrm{S}$ content and the highest $\mathrm{S}$ content $\left(10.06 \mu \mathrm{g} \mathrm{g}^{-1}\right)$ was recorded with USG-N $\mathrm{N}_{140}$ which was followed by USG-N $\mathrm{N}_{160}$, PU-N $\mathrm{N}_{180}$ and USG-N $\mathrm{N}_{180}$, but statistically identical with USG-N $\mathrm{N}_{160}$ (Table 6). This might be due to higher plant growth as well as higher nutrient uptake by the plant. The minimum $\mathrm{S}$ content $\left(7.06 \mu \mathrm{g} \mathrm{g}^{-1}\right)$ was found in the control plot. Variation in B content in post harvest soil was also found significant and the highest B content $\left(0.296 \mu \mathrm{g} \mathrm{g}^{-1}\right)$ was recorded in USG-N $\mathrm{N}_{140}$. This was also statistically similar to USG-N $\mathrm{N}_{160}$ and was followed by and PU-N ${ }_{180}$ (Table 6). It may be due to higher absorption and higher growth of the plant as promoted by $\mathrm{N}$. The minimum B content $(0.115 \mu \mathrm{g}$ $\mathrm{g}^{-1}$ ) was found with $\mathrm{N}$-control. The minimum $\mathrm{S}$ and $\mathrm{B}$ content in control plot may be due to no addition of those fertilizers.

Table 6. Effect of different levels of USG and PU on post-harvest soil nutrient status of broccoli field

\begin{tabular}{|c|c|c|c|c|c|}
\hline \multirow[t]{3}{*}{ Treatment } & \multirow[t]{2}{*}{ Total N } & \multirow{2}{*}{$\begin{array}{c}\text { Exchangeable } \\
\mathrm{K}\end{array}$} & \multicolumn{3}{|c|}{ Available nutrient } \\
\hline & & & $\mathrm{P}$ & $S$ & B \\
\hline & $(\%)$ & $(\mathrm{me} / 100 \mathrm{~g})$ & \multicolumn{3}{|c|}{$\left(\mu \mathrm{g} \mathrm{g}^{-1}\right)$} \\
\hline Control & $0.077 \mathrm{~b}$ & $0.188 \mathrm{a}$ & $17.59 \mathrm{a}$ & $7.06 \mathrm{c}$ & $0.115 \mathrm{c}$ \\
\hline USG-N $_{140}$ & $0.096 \mathrm{ab}$ & $0.172 \mathrm{ab}$ & $16.78 \mathrm{ab}$ & $10.06 \mathrm{a}$ & $0.296 \mathrm{a}$ \\
\hline USG-N 160 & $0.096 \mathrm{ab}$ & $0.156 \mathrm{bc}$ & $16.04 \mathrm{~b}$ & $9.39 \mathrm{a}$ & $0.294 \mathrm{a}$ \\
\hline USG-N $_{180}$ & $0.101 \mathrm{a}$ & $0.138 \mathrm{c}$ & $14.10 \mathrm{c}$ & $7.89 \mathrm{bc}$ & $0.202 \mathrm{~b}$ \\
\hline PU-N 180 & $0.099 \mathrm{a}$ & $0.157 \mathrm{bc}$ & $15.64 \mathrm{~b}$ & $9.01 \mathrm{ab}$ & $0.207 \quad b$ \\
\hline CV $(\%)$ & 5.93 & 9.63 & 4.61 & 7.50 & 7.38 \\
\hline $\begin{array}{l}\mathrm{SE} \\
( \pm 0.05)\end{array}$ & 0.005774 & 0.005774 & 0.4270 & 0.0 .3737 & 0.00577 \\
\hline
\end{tabular}

Means followed by uncommon letters are statistically different from each other at $5 \%$ level of probability by DMRT 


\section{Conclusion}

From the above study it appeared that USG-N is superior to PU-N in terms of yielding ability and quality parameters (Vitamin-C, $\beta$-carotene, and chlorophyll content) of broccoli. Nutrient uptake, nitrogen use efficiency and post harvest soil-N were also found to be higher with the use of USG-N. Such performance of USG-N was better with USG- $\mathrm{N}_{160}$. Nitrogen application@160 $\mathrm{kg}^{\mathrm{N}} \mathrm{Na}^{-1}$ in the form of USG along with recommended dose of other fertilizers may be suggested as the best combination of $\mathrm{N}$ rate and form of application for maximizing the yield and quality of broccoli in Silty Clay Loam Soil under Madhupur Tract (AEZ-28).

\section{References}

Abdelrazzag, A. 2002. Effect of chicken manure, sheep manure and inorganic fertilizers on yield and nutrient uptake by onion. Pakistan J. Biol. Sci. 5: 266-268.

Babik, I. and K. Elkner, 2002. The effect of nitrogen fertilization and irrigation on yield and quality of broccoli. Acta Horticulture. 571: 33-43.

Beecher, C. 1994. Cancer preventive properties of varieties of Brassica oleracea: A review. Amer. J. Clin. Nutri. 59: 1166-1170.

Bélec, C., S. Villeneuve, J. Coulombe and N. Tremblay. 2001. Impact of nitrogen fertilization on yield, hollow stem incidence and sap nitrate concentration in broccoli. Can. J. Plant Sci. 81: 765-772.

Black, C. A. 1965. Methods of soil analysis, Part-I and II. Amer. Soc. Agron. Inc. Pub. Madison, Wisconsin, U.S.A: 30-48.

Bullock D. G. and D. S. Anderson. 1998. Evaluation of the Minolta SPAD-502 chlorophyll meter for nitrogen management in corn. Journal of Plant Nutrition. 21(4): 741-755.

Chao-Jiong Xu, Rong-Fang Guo, Hui-Zhuan Yan, Jing Yuan, Bo Sun, Gao-Feng Yuan and Qiao-Mei Wang. 2010. Effect of nitrogen fertilization on ascorbic acid, glucoraphanin content and quinine reductase activity in broccoli floret and stem. Journal of Food, Agriculture \& Environment. 8 (1): 179-184.

Costa, C., D. Frigon, P. Dutilleul, L. M. Dwyer, V. D. Pillar, D. W. Stewart and D. L. Smith. 2003. Sample size determination for chlorophyll meter readings on maize hybrids with a broad range of canopy types. J. Plant Nutr. 26:1117-1130.

Craswell, E. T. and D. C. Godwin. 1984. The efficiency of nitrogen fertilizers applied to cereals in different climates. In: Tinker, P.B. and äuchli, A. (eds.): Advances in Plant Nutrition, vol. I. Praeger Publishers, New York. 1-55 Pp.

Everaarts A. P. and P. de Willigen. 1999. The effect of the rate and method of nitrogen application on nitrogen uptake and utilization by broccoli (Brassica oleracea var. italica). Netherlands Journal of Agricultural Science. 47: 201-214.

Fahey, J. W., X. Haristoy, P. M. Dolan, T. W. Kensler, I. Scholtus, K. K. Stephenson, P. Talalay and A. Lozniewski. 2002. Sulforaphane inhibits extracellular, intracellular and antibiotic-resistant strains of Helicobacter pylori and prevents benzo[a]pyrene- 
induced stomach tumors. Proceedings of the National Academy of Sciences of the United States of America. 99(11): 7610-7615.

FAO, 1988. Production year book.Food and Agricultural Organization. Rome, 157-158 Pp.

Goodlass, G., C. Rahn, M. A. Shepherd, A. G. Chalmers and F. M. Seeney. 1997. The nitrogen requirement of vegetables: comparisons of yield response models and recommendation systems. J. Hort. Sci. 72(2): 239-254.

Greenwood, D. J. and A. Draycott. 1988. Recovery of fertilizer-N by diverse vegetable crops: Process and models. In: Nitrogen efficiency in agricultural soils (Jenkinson D. S. and K. A. Smith Eds) Elsevier, London and New York, 46-61 Pp.

Greenwood, D. J., T. J. Cleaver, M. K. Turner, J. Hunt, K. B. Niendorf and S. M. H. Loquens. 1980. Comparison of the effects of nitrogen fertilizer on the yield, nitrogen content and quality of 21 different vegetable and agricultural crops. Journal of Agricultural Science. 95: 471-585.

Hala Kandil, Nadia Gad. 2009. Effects of inorganic and organic fertilizers on growth and production of brocoli (Brassica Oleracea L.). Factori şi Procese Pedogenetice din Zona Temperată S. nouă 8: 61-69.

Hunter, A. H. 1980. 'Soil fertility Analytical Service in Bangladesh' consultancy report, BJRI project phase II, BARC, Dhaka, Bangladesh.

Hussain, M. J., M. Y.Ali, M. A. Rahman, M. A. Helim Khan and M. M. Rahman. 2003. Application of urea super granule (USG) in vegetable crops: a profitable technology. Bangladesh Agricultural Research Institute and SFFP, Department of Agricultural Extension, 1-10 Pp.

Jackson, M. L. 1973. Soil Chemical Analysis. Prentice Hall of India Pvt. Ltd. New Delhi, India.

Kantety, R. V., E. van Santen, F. M. Woods and C. W. Wood. 1996. Chlorophyll meter predicts nitrogen status of tall fescue. Journal of Plant Nutrition. 19(6): 881-899.

Kapotis, G., G. Zervoudakis, T. Veltsistas and G. Salahas. 2003. Chlorophyll concentration in Amaranthusvlitus: correlation with physiological processes. Russ. J. Plant Physiol. 50: 442-444.

Karitonas R. 2001. Effect of nitrogen supply on yield and quality of broccoli. (Edn. Horst, W. J.; Schenk, M. K.; Bürkert, A.; Claassen, N.; Flessa, H.; Frommer, W. B.; Goldbach, H.; Olfs, H. W.; Römheld, V. et al., 2001. Plant nutrition: food security and sustainability of agro-ecosystems through basic and applied research. Fourteenth International Plant Nutrition Colloquium, Hannover, Germany 2001 pp. 298-299.

Khalil, M. I., U. Schmidhalter, R. Gutser and H. Heuwinkel. 2011. Comparative efficacy of urea fertilization via super granules versus prills on nitrogen distribution, yield response and nitrogen use efficiency of spring wheat. Journal of Plant Nutrition. 34 (6): 779-797.

Letey, J., W. M. Jarrell, N. Valoras and R. Beverly. 1983. Fertilizer application and irrigation management of broccoli production and fertilizer use efficiency. Agronomy Journal. 75:502-507. 
Liu, L., B. J. Shelp and G. A. Spiers. 1993. Boron distribution and translocation in fieldgrown broccoli (Brassica oleracea var. Italica). Canadian Journal of Plant Science. 73: $587-600$.

Lawlor, D. W. 2002. Carbon and nitrogen assimilation in relation to yield: mechanisms are the key to understanding production systems. Journal of Experimental Botany. 53(370): 773-787.

Magnusson, M. 2002. Mineral fertilizers and green mulch in Chinese cabbage (Brassica PekinensisRupr): effect on nutrient uptake, yield and internal tipburn. Soil Plant Sci. 52: $25-35$.

Masayasu Nagata and Ichiji Yamashita. 1992. Simple method for simultaneous determination of chlorophyll and carotinoids in tomato fruit. J. Iapan. Soc. Food Sci. Technol. 39(10), 925-928.

Masson, J., N. Trimbley and A. Gosselin, 1991. Effect on nitrogen fertilization and HPS supplementary lighting on vegetable transplant production. 1. Transplant growth. 2. Yield. Journal of the American Society for Horticulture Science. 116: 594-602.

Nasreen, Shamima, M. S. Haq, and M. S. Islam, 1992. Response of broccoli to N, P, K, $\mathrm{S}$ and Mo fertilization. Bangladesh J. Sci. Res. 10: 253-256.

Nazrul, M. I., M. J. Hussain, M. Y. Ali, and R. U. Shahmim. 2006. Use of urea super granule (USG) in vegetables cultivation: A profitable technology (Booklet). Published by Bangladesh Agricultural Research Institute, Gazipur. 8p.

Olsen, S. R, C. V. Cole, F. S. Watanable and L. A. Dean. 1954. Estimation of available phosphorus in soils by extraction with sodium bicarbonate. U. S., Dept. Agric. Circular: 207-215.

Ouda, B. A. and A. Y. Mahadeen. 2008. Effect of fertilizers on growth, yield, yield components, quality and certain nutrient contents in broccoli (Brassica oleracea). Int. J. Agri. Biol., 10(6): 627-32.

Page, A. L., R. H. Miller and D.R. Keeney. 1982. Methods of soil analysis. Part 2, $2^{\text {nd }}$ ed. Amar. Soc. Agron., Inc. Madi, Wis, USA.

Rashid, M. A., K. A. Billah, M. A. Mazid and F. Jameel. 1996. Nitrogen use efficiency of urea super granules and prilled urea in irrigated rice cultivation. Bangladesh Rice Journal. 7: 41-44.

Renata Wojciechowska, Stanisław RoŜek, Agata Rydz. 2005. Broccoli yield and its quality in spring growing cycle as dependent on nitrogen fertilization. Folia Horticulturae Ann. 17 (2): 141-152.

Rickard Mellgren. 2008. Effect of irrigation and nitrogen treatments on yield, quality, plant nitrogen uptake and soil nitrogen status and the evaluation of sap test, SPAD chlorophyll meter and Dualex to monitor nitrogen status in broccoli. Master thesis in the Horticultural Science Programme. 2008:4 $45 \mathrm{hp}$.

Riley, H. and I. Vågen. 2003. Critical N-concentration in broccoli and cauliflower, evaluated in field trials with varying levels and timing of fertilizer. Acta Horticulturae. 627: 241-249. 
Samotus, B., M. Leja and A. Scigalski. 1982. Porównanie czterech metod oznaczania kwasu askorbinowego w owocach i warzywach. Acta Agr. Silv., Ser. Agr. 21: 105122.

Thakur, O. P., P. P. Sharma and K. K. Singh. 1991. Effect of nitrogen and phosphorus with and without boron on head yield and stalk-rot incidence in cauliflower. Vegetable Sc. 18: 115-121.

Thompson, T. L., T. A. Doerge, R. E. Godin. 2002. Subsurface drip irrigation and fertigation of broccoli: I. Yield, quality, and nitrogen uptake. Soil Science Society of America Journal. 66: 186-192.

Tremblay, N. and P. Beaudet. 2006. Soil $\mathrm{N}_{\min }$ content and $\mathrm{P}_{2} \mathrm{O}_{5}$ export from vegetable crops in Quebec (Canada). Acta Horticulture. 700: 185-189.

Varvel, G. E., J. S. Schepers and D. D. Francis. 1997. Ability for in season correction of nitrogen deficiency in corn using chlorophyll meters. Soil Sci. Soc. Am. J. 61:12331239.

Wang, Q., J. Chen, and Y. Li. 2004. Nondestructive and rapid estimation of leaf chlorophyll and nitrogen status of peace lily using a chlorophyll meter. Journal of Plant Nutrition. 27(3): 557-569.

Yoldas, F., S. Ceylan, B. Yagmur, and N. Mordogan. 2008. Effect of nitrogen fertilizer on yield quality and nutrient content in broccoli. Journal of Plant Nutrition.31: 1333-1343.

Zaman, S. K., M. A. Razzaque, S. M. R. Karim and A. U. Ahmed. 1993. Evaluation of prilled urea and urea super granule as nitrogen sources for upland aus rice. Bangladesh Rice Journal. 4:42-46.

Zebarth, B. J., P. A. Bowen and P. M. A. Toivonen. 1995. Influence of nitrogen fertilization on broccoli yield, nitrogen accumulation and apparent fertilizer-nitrogen recovery. Canadian Journal of Plant Science. 75(3): 717-725. 